\title{
Branding Instead of Product Innovation: A Study on the Brand Personalities of the UK's Electricity Market
}

\author{
Richard Rutter, ${ }^{1,2}$ Konstantinos J. Chalvatzis, ${ }^{1,3}$ Stuart Roper ${ }^{4}$ \\ and Fiona LetTice ${ }^{1}$ \\ ${ }^{1}$ Norwich Business School, University of East Anglia, Norwich, UK \\ ${ }^{2}$ School of Business, Australian College of Kuwait, Kuwait \\ ${ }^{3}$ Tyndall Centre for Climate Change Research, University of East Anglia, Norwich, UK \\ ${ }^{4}$ Huddersfield Business School, University of Huddersfield, Huddersfield, UK
}

\begin{abstract}
This study extends understanding of and demonstrates the importance of corporate branding in the energy sector. We analyse the relationship between branding and consumer switching behaviour among the UK's Big Six electricity providers. Since privatization companies have competed against each other, but to the consumer they often appear to have very similar product offerings; firms also face criticism from consumer groups regarding confusing and difficult to compare pricing schemes. This study examines the use of corporate branding to enhance differentiation and specifically examines the influence of brand consistency and brand personality on the retention of customers. Consumers, who find it difficult to compare tariffs, may be influenced by more demonstrable factors like branding. We demonstrate the importance of longitudinal brand consistency, as well as the personality dimension excitement, which when communicated strongly has the greatest influence on customer retention levels. This work contributes to branding theory, demonstrating that brand personality does differentiate otherwise homogeneous (and low-contact) services. Managerial implications are presented for brands seeking to improve consumer retention.
\end{abstract}

Keywords: energy sector branding; energy branding; brand personality

\section{Introduction}

Consumer energy markets are complex (Gangale et al. 2013) and it can be extremely difficult for consumers to directly compare offerings between the main energy providers (Chioveanu and Zhou 2013). It is difficult for customers to accurately compare tariffs and prices with many customers not signed up to the package that is cheapest for them and often unwilling to switch providers (McDermott 2013). Since the UK energy sector's privatization, marketing and branding have become increasingly important as methods of promotion and differentiation for providers (Shippee 1999; Hartmann and Apaolaza-Ibáñez 2007). Energy companies are confronted with the threat of customer defection, as well as having to compete against each other, poaching each

Correspondence: Richard Rutter, University of East Anglia, Norwich Business School, Norwich, UK. E-mail: r.rutter@uea.ac.uk other's' customers being the prize (Walsh et al. 2006). The complexity of UK energy tariffs and the lack of transparent package comparability have been criticized by the media and government (Richards and White 2014). Energy companies have responded by focusing on corporate marketing and branding in order to attract new consumers, but also to improve existing customer satisfaction (Payne and Frow 1997).

The energy sector provides an ideal landscape for a brand-based approach since energy as a product or service is indistinguishable between providers. We focus on the residential electricity market because it is larger (in terms of the number of customers) than the commercial and industrial energy markets. Commercial and industrial customers also have access to bespoke energy services, whereas residential energy services are more generic, allowing for market-wide comparisons. The anthropomorphizing of brands in general aids consumer emotional engagement with services (independent of their technical characteristics) and construction of a brand 
personality provides a useful heuristic device. The aim of this research, therefore, is using the UK residential energy sector as an example, to test the robustness of brand personality theory upon consumer loyalty. The research questions driving this research are: (1) does a well-defined and consistently communicated brand personality enhance the brand of energy providers and mitigate homogenization of their services? And (2) can a more demonstrable brand personality prevent consumers switching to rival providers? To the best of our knowledge this is the first time that market-wide switching data are used in relation to branding research for the UK power market.

\section{Privatization and branding in the UK electricity market}

Consumer behaviour research highlights that consumers resist making difficult decisions between products or services which are difficult to compare, opting for comparisons within dimensions which can be more easily compared (Ariely 2009). Consumers are more likely to be influenced by factors that they can easily relate to, for example the energy provider's brand (Hartmann and Apaolaza-Ibáñez 2007), and in particular the brand behaviour and personality (Clancy and O'Loughlin 2002; Hartmann and Apaolaza-Ibáñez 2012). A brand personality helps to create a level of intuitive appeal and synergy between a brand and its customers (Plummer 1985).

Although well researched in many areas, such as automobiles (Fetscherin and Toncar 2010), cosmetics (Guthrie et al. 2008), education (Rutter et al. 2016), fashion (Rageh Ismail and Spinelli 2012), health (Pinto and Yagnik 2017), luxury (Sung et al. 2015), politics (Rutter et al. 2015), sport (Braunstein and Ross 2010) and tourism (Opoku et al. 2007), brand personality research is underdeveloped in the energy sector, despite brand management becoming increasingly important in practice. Existing energy research (e.g. Müller et al. 2007, Kaenzig et al. 2013 and He and Reiner 2016) has emphasized the importance of price and tariff data, rather than branding strategy, as a means to attract and retain consumers. More recently limited research has emerged on marketing and branding in the energy sector. For example, Herbes and Ramme (2014) explored the strategic marketing differentiation of renewable power suppliers in Germany. Paladino and Pandit (2012) classified the renewable energy utilities in Australia as service providers and focused on their approach to residential consumer recruitment and retention on renewable energy tariffs. Finally, it has been identified that identity signalling has positive effects in renewable energy demand in the Swedish residential electricity market (Hanimann et al. 2015).
While renewable (or green) energy clearly provides a means of service differentiation, regular power utilities have much less to differentiate on. Power sector branding research has been triggered in the past by the privatization and liberalization initiatives that reformed formerly stateowned and controlled utilities to competitive corporations. Early branding campaigns during the mid-1990s in Sweden aimed to ease public perception that the electricity firms were bureaucratic and inflexible organizations and only targeted prime customers (Summerton 2004). Trustworthiness as a branding feature has been identified by Apaolaza-Ibáñez et al. (2006) as one of the main drivers for customer loyalty in the Spanish residential electricity market. For the same market, Hartmann and Apaolaza-Ibáñez (2007) suggest that brand trust is as important as customer satisfaction for customer loyalty.

The UK energy sector is particularly interesting because it was the first liberalized energy market, a precursor to similar moves in many other countries, including the US (Giulietti et al. 2005). Until the 1980s, the UK energy sector was under national control, and its privatization was (and it could be argued, still is) a controversial political decision (Hammond et al. 1985; Kay and Thompson 1986). Throughout the, 1990s, the UK's energy sector went through a series of consolidations and mergers, which have given rise to the current structure (Leggett 2013), in which the Big Six energy companies account for over $90 \%$ of the UK residential market share (BBC 2013a). The Big Six are British Gas, SSE, E.ON UK, Scottish Power, EDF Energy and npower. The first two companies are the largest in terms of customer base and are British owned (House of Commons Work and Pensions Committee and Rooney 2009); E.ON UK and npower are owned by German investors (E. ON and RWE respectively), whilst Scottish Power is now controlled by Spanish parent organization Iberdrola (Leggett 2013). EDF Energy is owned by the French state-controlled EDF, who also own British Energy, making EDF the largest producer of energy within the UK.

The UK's residential energy market claims to have the largest number of consumers to have switched supplier, although there has recently been a steep decline in switching (Bawden 2015). Electricity utilities are frequently part of the political discourse where mainstream political party manifestos feature radical proposals for capping energy prices (Landale 2017; Milligan 2017). Energy utilities do not engage in innovative actions either in production (Zafirakis et al. 2015) or consumption side (Pothitou et al. 2017, 2016) and are often criticized for their tariff policies and underinvestment. The latter makes the UK power market uniquely constrained between low production margins and the necessity for the extensive reforms required to meet strict environmental targets. 
Customer choice within the energy sector

Previous research indicates that energy is perceived as a commodity as providers use price perception as the number one factor to influence a consumer's choice to change provider (Goett et al. 2000; Watson et al. 2002; Rowlands et al. 2004). However, given the complexity of tariffs and lack of transparent comparability (Rommel and Meyerhoff 2009; Bonk 2012), other factors such as loyalty and brand perception have become increasingly important (Hartmann and Apaolaza-Ibáñez 2007; García-Acebrón et al. 2010). Research by Hartmann and Apaolaza-Ibáñez (2007) also suggests that brand trust and associations (for example: innovation and environmental commitment) affect consumer perception and subsequent loyalty, beyond satisfaction or even switching cost.

The success of price comparison websites (PCWs) increases the need for brand related action to avoid a company being labelled as a commodity. PCWs are a useful way for consumers to easily compare and contrast energy tariffs and 14 PCWs account for $90 \%$ of consumer switching activity in the UK. However, the number of customers switching between electricity providers has been falling steadily since, 2008, and reached its lowest level in the second quarter of, 2013 (BBC 2013b). Typically this has been explained as inertia, as consumers find it difficult to compare over 900 tariffs (McDermott 2013). However, another interpretation could be that the increased branding activities and differentiated brand personalities of the energy providers is increasing consumer loyalty and thus reducing switching behaviour, which we will test in this research.

\section{Corporate branding and the defence against commoditization}

Balmer (2013: 724) suggests that our understanding of brands has now progressed to a corporate brand orientation, whereby the corporate brand acts as the cornerstone, indeed 'the centripetal force - that informs and guides the organization, especially in relation to its core philosophy and culture'. As an example, Brei and Böhm (2014), discuss the interesting case of Volvic Water that through its campaign to provide 10 litres of drinking water in Africa for every 1 litre sold in western countries turned what was a commodity product into a pioneering corporate brand, ready to address the major issues facing the world. In such ways corporate brands have become more relevant to peoples' lives as consumers themselves have become more demanding of brands (Roper and Fill 2012). This is synonymous with the rise of the corporate brand in recent years where the company itself becomes the brand, rather than an individual product or service. With this change has come the need for greater transparency from the brand, and as cited above, greater responsibility (Gyrd-Jones et al. 2013). In addition to these factors, Ind and Bjerke (2007) also cite complexity as an important criterion of the corporate brand; that is it can be responsible to multiple stakeholders in many countries and regions.

Lekakis (2012) considers the complexity and politicization of corporate branding specifically within the efforts to brand the otherwise commodified products that come under the 'Fair Trade' label. Corporate branding has also helped to provide a recognizable banner around which an industry can group and assume a greater power e.g. the Marlborough wine region in New Zealand.

Our paper considers the success of corporate branding and specifically brand personality in transforming a commodity market. In looking at commodity branding historically, Wengrow et al. (2008) discusses the development of the packaged goods industry. We now recognize fast moving consumer goods as the wellestablished classic brands, with a history and heritage created by decades of marketing activity. What may once have been seen as commodities have long been differentiated by branding including such basics as bread or cereal. Corporate branding can be utilized to help further delineate that which the consumer still finds difficult to distinguish, for example, the provision of consumer electricity.

It is argued that many businesses are under attack from a new wave of commoditization (Holmes 2016) with the advent of facilities such as price comparison sites reducing many areas such as insurance and of course energy, into commodities whereby price is seen as the key differentiator. Mingione (2015), in a meta-analysis of corporate branding literature acknowledges the often confused nature of corporate branding theory and states that because of this there is no accepted way of managing a corporate brand. However, one of three imperatives suggested for mangers of corporate brands is the coconstruction of brand meanings. The corporate brand personality can be the method by which the corporate brand is communicated to the multiple stakeholders that are a key feature of the corporate as opposed to the product brand (Roper and Fill 2012).

\section{Brand personality}

King (1970: 14) states that "people choose their brands the same way they choose their friends. In addition to the skills and physical characteristics, they simply like them as people'. Within the energy sector there is increased interest in brands as anthropomorphic entitles and Clancy and O'Loughlin (2002) found that energy providers' brand personalities affect consumer aversion. The importance of brand personality within the context of service brands is acknowledged (Spielmann and Babin 2011; Sirianni et al. 2013), specifically its utility as a tool 
for positioning using Aaker's (1997) model of brand personality.

Aaker's (1997) seminal work considers the brand as if it were a person. This is otherwise known as anthropomorphization (Patterson et al. 2013). It involves attributing human characteristics to the brand, and is a way to create uniqueness by reinforcing those human psychological values to which consumers relate, beyond price, performance and functionality. Aaker (1997) determined five key brand personality dimensions: sincerity, excitement, competence, sophistication and ruggedness. In service organizations, where the core service is identical, developing and promoting a unique brand personality can become a key source of differentiation. Failure to do so would leave companies in a commodity market whereby the cheapest provider wins and in the case of the energy firms this would result in significant switching behaviour. Utilizing the brand personality dimensions, Opoku et al. (2007) constructed a dictionary which enables researchers to analyse the brand personality being communicated through marketing text and allows direct comparison between brands over Aaker's five dimensions. Due to the homogenous nature of the energy industry, the development of a strong brand personality (Novak and Lyman 1998), is important to position and communicate information about the organization to stakeholders.

Thomas and Jenifer (2016) consider brand personality from an employer brand personality perspective in the IT sector. Harris and Fleming (2005) study the banking sector and suggest that human personality traits should inform the service personality of the brand. A different cultural perspective is taken by Ahmed and Jan (2015), who extend Aaker's original work on brand personality by suggesting an Islamic brand personality scale. Ugolini et al. (2014) consider the different gender associations within the personalities of service brands. Shehu et al. (2016) consider the impact of brand personality on nonprofit organizations, namely charities, whilst Tsiotsou (2012) look at a specific area of the service sector, that is personality of sports teams.

Spielmann and Babin (2011) expand research into personality by looking at the importance of personality amongst several service industries and the personality of the industry itself rather than that of the individual brand name. Their work, however, relates to face-to-face high contact services. Our contribution is to look at the impact of brand personality and its impact on switching behaviour or customer loyalty on a low contact service.

de Chernatony and Segal-Horn (2003) comment upon the uniqueness of a particular service and the image that the service provider transmits with his/her behaviour can be a means by which service brands differentiate themselves. As with Spielmann and Babin (2011), however, their work looks at services where there is a significant interaction between service provider and customer. Our work fills a gap in the literature by considering the importance of brand personality and brand consistency for an industry where there is little and often no interaction between service provider and customer.

\section{Brand personalities within the big six}

The Big Six are increasingly turning to brand consultants when attempting to improve their proposition. For example, EDF engaged the marketing company Interbrand (Brownsell 2009), which developed a new 'brand platform' to ensure clarity and consistency (EDF 2013). Interbrand (2012a) describe EDF's brand positioning as 'EDF [is] a committed, innovative brand with expert knowledge of the electricity business'. This position, the company hopes, will be embodied within their new tagline of 'The Electricity Company'.

British Gas, which is the largest of the Big Six, has taken significant steps to communicate a stable brand personality and initiated a brand identity re-launch (Chapman 2011). Significant resources appear to have been dedicated to this process, with the organization creating the position of 'brand design manager' describing the role as 'responsible for creative strategy and output in line with the brand personality' (Brocklehurst 2013) and to ensure that 'all elements of our marketing deliver the company's strategy to be a modern, customer-led company' (Chapman 2011).

Similarly, npower's brand manager has stated a desire to 'put the customer at the heart of the business' (Brownsell 2013). In order to do that, npower need to 'earn the right' to have a dialogue with customers. Whilst it is unlikely that consumers will come to love any of the Big Six, npower believes that it is possible for them to become 'trusted and respected'. Ultimately, npower describes the challenge as moving from a situation in which 'you put your hands over the logo and you just cannot tell them [the Big Six] apart', to building a brand 'which has distinction [and] that is recognised for its own [brand] personality in the market'. In essence, this approach recognizes the power of brand identity when attempting to persuade consumers to switch providers. Rather than doing so simply on the basis of superior financial offers, the Big Six are increasingly looking to build a long-term brand personality with which consumers will identify.

Each of the Big Six has the same ultimate aim. As can be seen from the examples above, these organizations wish to be viewed as customer-focused and as offering a fair deal to consumers. However, attempts to differentiate their brands would be pointless if each brand personality being constructed by the Big Six was identical. Instead, there seem to be subtle but important differences in the ways that each company is choosing to communicate with its domestic audience. Further, an analysis of the language 
used in branding materials and outward-facing communications would reveal the different strategies being used by the Big Six in an attempt to achieve the same ultimate goals. As will be seen, however, each of the Big Six appears to be communicating their chosen brand personality differently. As we later demonstrate, some are more effective than others.

\section{Theoretical framework}

A brand's personality is stronger and clearer if the dimensions are coordinated, if the personality is distinctive, and if the personality is consistent between channels and over time (Batra et al. 1993; Sung and Kim 2010). This research aims to analyse the different brand personalities constructed by energy brands and to link these to performance. This section, therefore, hypothesizes relationships between the brand and consumer retention.

\section{Brand personality strength}

Branding within the energy sector is reliant on marketing communications which position the brand so that it occupies a distinct and valued position within consumers' minds (Novak and Lyman 1998). Strong and distinctive brand communication may increase the level of consumer attention paid towards the brand, which in turn creates strong and more favourable brand associations (Freling and Forbes 2005). Previous studies identified that brands communicate certain dimensions more strongly than others, for example, competence in logistics (Rutter et al. 2017b), sincerity in higher education (Rutter et al. 2017a) and ruggedness in African tourism destinations (Pitt et al. 2007), and that brand personality strength and uniqueness is a key driver of performance (Freling and Forbes 2005). Brakus et al. (2009) explain that particular dimensions of brand personality can increase loyalty and research has identified that consumers identify with particular dimensions of personality more than others and some dimensions are more relevant within specific sectors, for example, ruggedness of African tourism destinations (Opoku and Hinson 2006), and competence in politics (Rutter et al. 2015). Further, Sung and Kim (2010) provide evidence that brand personality traits, created in marketing communications, can be used as a central driver in enhancing persuasion. Therefore, our first hypothesis seeks to ascertain whether energy providers with different brand personalities have higher and lower levels of consumer switching.

First, competence is the dimension most likely to be related to the sector (Sung and Kim 2010). Given the importance of an energy brand being competent, we speculate higher levels of competence will be associated with less switching. Second, excitement is perceived more positively in line with persuasion attempts (Guèvremont and Grohmann 2013), in this case to retain a customer, and we speculate a link between higher levels of excitement and less switching. Third, ruggedness is a construct closely related to emotions (Viktoria Rampl and Kenning 2014), often perceived as more 'outdoorsy' and tough; therefore, we speculate closer attachment and less switching. Fourth, sincerity is linked to trust in the brand, which represents honesty and reliability (Moorman et al. 1993). Given the nature of energy and an assumption of reliability, we propose that higher levels of Sincerity would not be linked to less switching. Fifth, Sophisticated brands are most likely to be associated with higher costs and exclusivity (Maehle et al. 2011) and given the emphasis on the lowest cost tariffs being switched to, perceived higher price would be less desirable to consumers. Therefore:

Hypothesis 1. Brand personality strength of (a) competence, (b) excitement and (c) ruggedness will be significantly and negatively related to consumer switching. Brand personality strength of (d) sincerity and (e) sophistication will be significantly and positively related to consumer switching.

\section{Brand personality consistency}

Global brands try to maintain brand consistency when communicating their brand qualities (Arruda 2009; Interbrand 2012b). This leads to consumer understanding of what the brand stands for, along with an ability to predict its future behaviour (Erdem and Swait 1998; Keller 1999; Lange and Dahlén 2003). Navarro-Bailón (2012) argues that brand consistency is integral to brand campaigns and Arruda (2009) states that brand communications should be consistent regardless of the media chosen. This consistency then results in higher levels of performance such as consumer-based brand equity (Pike 2004) over time and as part of the long-term strategy (de Chernatony 2010; Knox and Bickerton 2003; Argenti and Druckenmiller 2004; Matthiesen and Phau 2005). Aaker (1996a) and Kapferer (2008: 43) argue that brands can only be developed through 'consistently being consistent' over a period of time. Consistency is essential for successful brands, but organizational complexity and a lack of departmental commercial focus (Brookes 2003) can impact upon the level to which brands are able to communicate consistently (Chapleo 2007). This renders the energy sector context of particular interest when examining the relationship between brand consistency and performance. Therefore, our second hypothesis tests the relationship between brand personality consistency and consumer switching levels: 
Hypothesis 2. Brand personality consistency will be significantly and negatively related to consumer switching.

If a brand is perceived as being less authentic, it can erode trust in that brand (Beverland 2009; Eggers et al. 2012). Institutions which have achieved a high level of brand authenticity are often less likely to over sell themselves (Interbrand 2012b). Grant (1999: 98) stated that 'authenticity is the benchmark, against which all brands are now judged'. Eggers et al. (2012) found that consistency and congruency were positively related to brand authenticity, whilst customer orientation was not. Becker and Palmér (2009) also argue that if the image a brand is communicating is not congruent with reality, then it is not likely to be effective. Ergo, brands that are more authentic and consistent are more believable. A stakeholder approach to organizational identity infers that communication documents are contextualized and directed to different stakeholders groups (Roper and Davies 2007), perhaps at the expense of overall brand consistency. Therefore, the final hypothesis is:

Hypothesis 3. Brand personality consistency (between internal and external communications) will be significantly and negatively related to consumer switching.

\section{Methodology}

The literature review highlighted growing anecdotal evidence to suggest the importance of a strong brand and personality as a means of differentiation within the energy sector; therefore, this study was designed to empirically test these assertions and considers energy brands through a brand personality lens as well as the effect of communication on performance.

\section{Sample}

The Big Six energy providers were sampled, as they represent over $90 \%$ of all energy supplied in the UK consumer energy market. British Gas (20 million customers); EDF Energy (5.7 million customers); E.ON UK (5.3million customers); npower (6.5 million customers); Scottish Power (5.2 million customers); and SSE (9.6 million customers).

\section{Variables}

Energy brand performance was measured via a unique dataset of switching data covering the period of, 20132015. This included the number of consumers switching divided by the total number of customers for each energy brand for each quarter over a 24-month period. This measures an energy brand's capacity to retain customers.

In this study, personality and communication consistency are key measures of brand. The UKRN's (UK Regulators Network) report, 'Consumer engagement and switching' (2014) on behalf of Ofgem (Office of Gas and Electricity Markets) in the UK explained that the 'internet tends to dominate' consumer switching decisions, particularly the provider websites, commonly used to access comparative information on alternative providers. Table 1 highlights that the Big Six providers averaged approximately 700,000 unique visitors per month in, 2014, and these visitors spent an average of 7 minutes and 24 seconds reading the provider's website. Brand personality communicated by the company's website text provides a measure of brand personality strength.

The brand personality communicated by the website text in 2013 compared with 2015 measures brand personality consistency over time and is consistent with the time period for the switching data available. The website provides information to consumers, delivering detailed information about the energy company and its product. The brand personality communicated by the website text in 2013 compared with the brand personality communicated by the annual report in 2013 measures brand personality consistency between communication channels. All energy companies produce an annual report, which provides details of the company's activities to stakeholders. The annual report of a company is a means by which to communicate the corporate brand to external stakeholders (Roper and Fill 2012; Spear and Roper 2013; Daglish 2016), but which must also resonate with internal stakeholders, otherwise it will fail to gain credibility (Heugens 2002; Dowling 2006). Table 2 summarizes the variables used in this research.

Brand consistency across channels was measured using t-tests. Each brand personality dimension over each medium was tested for significance of difference. If a brand personality dimension is significantly different between media, it is classed as inconsistent. Dimensions that were not significantly different were classed as consistent. For the purposes of this research, a non-

Table 1 Big Six website statistics (average per month in, 2014) (source: Alexa)

\begin{tabular}{llrl}
\hline $\begin{array}{l}\text { Energy } \\
\text { provider }\end{array}$ & URL & $\begin{array}{l}\text { Unique hits } \\
\text { per month }\end{array}$ & $\begin{array}{l}\text { Average time } \\
\text { on site }\end{array}$ \\
\hline British Gas & britishgas.co.uk & $1,400,000$ & $8 \mathrm{~m} \mathrm{2} \mathrm{s}$ \\
E.ON UK & eonenergy.com & 830,000 & $6 \mathrm{~m} \mathrm{7} \mathrm{s}$ \\
EDF Energy & edfenergy.com & 700,000 & $7 \mathrm{~m} \mathrm{47} \mathrm{s}$ \\
RWE npower & npower.com & 580,000 & $8 \mathrm{~m}$ \\
SSE & sse.co.uk & 120,000 & $5 \mathrm{~m} 18 \mathrm{~s}$ \\
Scottish Power & scottishpower.co.uk & 580,000 & $10 \mathrm{~m} \mathrm{~s} \mathrm{~s}$ \\
\hline
\end{tabular}


Table 2 Variables

\begin{tabular}{ll}
\hline Variable & \multicolumn{1}{c}{ Description and measure } \\
\hline Brand Personality & $\begin{array}{c}\text { Brand personality strength measured by the relative frequency of references to each of the } 5 \text { dimensions of brand } \\
\text { personality. } \\
\text { Measured through an assessment of whether or not the } 5 \text { dimensions of brand personality are significantly different } \\
\text { (see Figure 4) between channels: (1) Consistency between the website in, } 2013 \text { and, 2015; }\end{array}$ \\
Brand Consistency & $\begin{array}{l}\text { (2) Consistency between the website and annual report in, } 2013 \\
\text { The number of customers switching as a proportion of the total number of customers (churn) for each energy provider. }\end{array}$ \\
Switching &
\end{tabular}

significant difference demonstrates consistency, as opposed to numerical equality as constancy. Thus inconsistency is rejected at the $95 \%$ or higher level $(p>0.05)$. The example in Figure 1 highlights that excitement, competence, sophistication and ruggedness were consistent, whilst sincerity was inconsistent.

\section{Data collection}

Each energy company's website was downloaded, once in, 2013 and again in, 2015. Starting from the homepage, each website was initially 'spidered' (an automated and methodical process to extract data from a website), which provided a list of URLs to be manually checked. Limitations in the methodology concerned data reliability (Krippendorff 2004) and checks were made to reduce bias. The researcher defined inclusion and exclusion criteria to ensure that the pages saved were related to residential customers and excluded contractual and policy pages, as detailed in Table 3.

Two researchers were trained and then independently analysed and coded a selection of webpages and compared results. Discrepancies were discussed and resolved. Both researchers used the same instructions and criteria and the procedure was adjusted until high inter-coder reliability was obtained. Next, during the data collection stage, one trained researcher examined and made judgments about all webpages in the sample. Fifty per cent of the webpages were randomly selected and independently checked by a second researcher.

At the same time, each energy company's annual report was requested. Optical character recognition software then scanned the document to transfer the paper-based text to a digital format. This was able to convert $50-60 \%$ of the documents into a digital format. Each page of each document was then compared to the original text and the remaining data was entered manually. This process resulted in 4,002,878 words from the websites and reports for the six energy companies, shown in Table 4.

\section{Content analysis}

The collected data were content analysed using Opoku et al.'s (2007) dictionary developed from Aaker's (1997) model of brand personality. Content analysis is a research technique to objectively, systematically and quantitatively describe the content of communication. It has been used before in research for marketing and branding (Berelson 1952; Kassarjian 1977); specifically to analyse brand

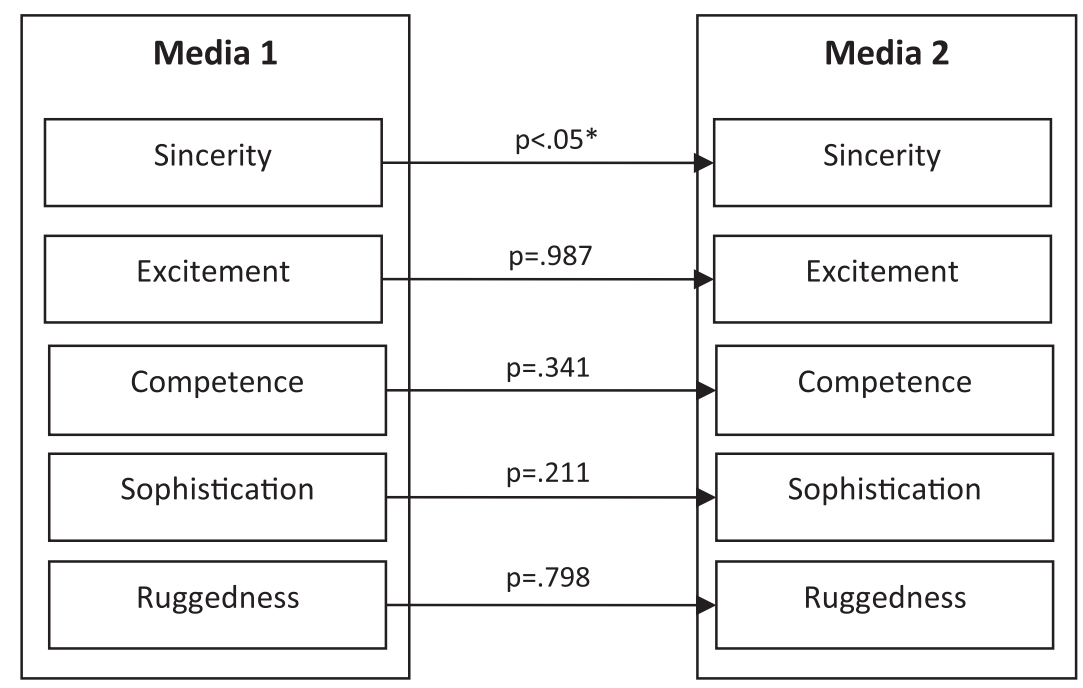

Figure 1 t-tests conducted between each dimension of each channel. 
Table 3 Criteria used for the data collection process

\begin{tabular}{ll}
\hline Sections to be saved & \multicolumn{1}{c}{ Sections not to be saved } \\
\hline - Homepage & - Any link that goes away from the main URL \\
- About the company & - Customer account based pages (login, meter reading etc.) \\
- Gas and electricity information & - Business related pages \\
- Home services information & - Terms and Conditions (contractual, privacy policy, access, legal, etc.) \\
- Research information & - Contact information \\
- News and events & - Procedural and help information \\
& - Tariff and price information
\end{tabular}

Table 4 Selected words from Opoku's brand personality dictionary

\begin{tabular}{ll}
\hline Trait & \multicolumn{1}{c}{ Selected words } \\
\hline Competence & Competent, guarantee, responsible, staunch, unshakable \\
Sincerity & Authentic, affable, down-to-earth, heartfelt, realistic \\
Sophistication & Celebrated, charismatic, distinguished, graceful \\
Ruggedness & Challenge, endeavour, rigorous, tough, unrestrained \\
Excitement & Bold, courageous, fresh, inventive, stirring \\
\hline
\end{tabular}

personality (Pitt et al. 2007; Clemenz et al. 2012; Haarhoff and Kleyn 2012). Content analysis provides a powerful way to analyse marketing communications, specially textual content of marketing media (Krippendorff 2004). The Opoku dictionary, based on Aaker's brand personality framework, consists of five dimensions: sincerity, excitement, competence, sophistication and ruggedness, that are used to assess brand personality from text-based media to produce frequency counts for the number of brand personality words associated with each dimension. The dictionary also included the dimensions, traits and facets themselves and an example of words associated with each dimension can be seen in Table 4. This is a comprehensive and validated dictionary that is able to test the brand personality dimensions contained within texts, as opposed to most approaches to measuring brand personality which are aimed at identifying how consumers perceive brand personality. It was therefore the approach most suited to the aims of this research.

The dictionary shifts the focus from how the consumers perceive brand personality, to what the organizations as brands are saying about themselves. For example Table 5 shows that British Gas communicated 1,000 words associated with competence in their annual report and 2,399 and 874 words through their website in, 2013 and, 2015 respectively. Table 6 shows the relative frequencies, highlighting that British Gas's website was less wordy in, 2015, therefore, the relative frequency of competence was $31.31 \%$ and $25.7 \%$ in, 2013 and, 2015 respectively.

\section{Statistical analysis}

Multiple Correspondence Analysis (MCA) was performed on the word counts, as although it is possible to identify certain distinctive patterns in Table 5, it is easier to understand, represent and interpret these patterns

Table 5 Brand personality frequency counts and total number of words

\begin{tabular}{|c|c|c|c|c|c|c|c|}
\hline & & Competence & Excitement & Ruggedness & Sincerity & Sophistication & Total words \\
\hline \multirow[t]{6}{*}{ Annual Report } & British Gas & 1000 & 429 & 193 & 547 & 36 & 113,311 \\
\hline & E.ON UK & 281 & 93 & 33 & 103 & 10 & 110,939 \\
\hline & EDF Energy & 530 & 468 & 98 & 402 & 36 & 29,968 \\
\hline & RWE npower & 388 & 332 & 116 & 416 & 20 & 99,650 \\
\hline & SSE & 266 & 176 & 44 & 181 & 8 & 112,047 \\
\hline & Scottish Power & 891 & 359 & 163 & 511 & 68 & 40,396 \\
\hline \multirow[t]{6}{*}{ Website (2013) } & British Gas & 2399 & 1422 & 467 & 3194 & 180 & 426,198 \\
\hline & E.ON UK & 1727 & 827 & 189 & 2090 & 88 & 322,756 \\
\hline & EDF Energy & 2140 & 1113 & 680 & 2482 & 181 & 343,842 \\
\hline & RWE npower & 652 & 557 & 98 & 2266 & 55 & 165,035 \\
\hline & SSE & 834 & 494 & 132 & 1547 & 74 & 183,160 \\
\hline & Scottish Power & 722 & 293 & 33 & 1114 & 7 & 90,323 \\
\hline \multirow[t]{8}{*}{ Website (2015) } & British Gas & 874 & 513 & 173 & 1651 & 184 & 223,020 \\
\hline & E.ON UK & 2609 & 1053 & 318 & 3081 & 79 & 541,484 \\
\hline & EDF Energy & 1824 & 1307 & 465 & 2078 & 132 & 472,060 \\
\hline & RWE npower & 1649 & 1774 & 314 & 5939 & 255 & 507,180 \\
\hline & SSE & 685 & 427 & 95 & 1298 & 65 & 155,577 \\
\hline & Scottish Power & 264 & 185 & 35 & 356 & 4 & 65,932 \\
\hline & & & & & & Total & $4,002,878$ \\
\hline & & & & & & Mean & 222,382 \\
\hline
\end{tabular}


Table 6 Brand personality proportions and of total words

\begin{tabular}{|c|c|c|c|c|c|c|c|}
\hline & & Competence & Excitement & Ruggedness & Sincerity & Sophistication & $\%$ of total words \\
\hline \multirow[t]{6}{*}{ Annual Report } & British Gas & $45.35 \%$ & $19.46 \%$ & $8.75 \%$ & $24.81 \%$ & $1.63 \%$ & $1.95 \%$ \\
\hline & E.ON UK & $54.04 \%$ & $17.88 \%$ & $6.35 \%$ & $19.81 \%$ & $1.92 \%$ & $0.47 \%$ \\
\hline & EDF Energy & $34.55 \%$ & $30.51 \%$ & $6.39 \%$ & $26.21 \%$ & $2.35 \%$ & $5.12 \%$ \\
\hline & RWE npower & $30.50 \%$ & $26.10 \%$ & $9.12 \%$ & $32.70 \%$ & $1.57 \%$ & $1.28 \%$ \\
\hline & SSE & $39.41 \%$ & $26.07 \%$ & $6.52 \%$ & $26.81 \%$ & $1.19 \%$ & $0.60 \%$ \\
\hline & Scottish Power & $44.73 \%$ & $18.02 \%$ & $8.18 \%$ & $25.65 \%$ & $3.41 \%$ & $4.93 \%$ \\
\hline \multirow[t]{6}{*}{ Website (2013) } & British Gas & $31.31 \%$ & $18.56 \%$ & $6.10 \%$ & $41.69 \%$ & $2.35 \%$ & $1.80 \%$ \\
\hline & E.ON UK & $35.09 \%$ & $16.81 \%$ & $3.84 \%$ & $42.47 \%$ & $1.79 \%$ & $1.52 \%$ \\
\hline & EDF Energy & $32.44 \%$ & $16.87 \%$ & $10.31 \%$ & $37.63 \%$ & $2.74 \%$ & $1.92 \%$ \\
\hline & RWE npower & $17.98 \%$ & $15.35 \%$ & $2.70 \%$ & $62.45 \%$ & $1.52 \%$ & $2.20 \%$ \\
\hline & SSE & $27.07 \%$ & $16.04 \%$ & $4.29 \%$ & $50.21 \%$ & $2.40 \%$ & $1.68 \%$ \\
\hline & Scottish Power & $33.28 \%$ & $13.51 \%$ & $1.52 \%$ & $51.36 \%$ & $0.32 \%$ & $2.40 \%$ \\
\hline \multirow[t]{6}{*}{ Website (2015) } & British Gas & $25.74 \%$ & $15.11 \%$ & $5.10 \%$ & $48.63 \%$ & $5.42 \%$ & $1.52 \%$ \\
\hline & E.ON UK & $36.54 \%$ & $14.75 \%$ & $4.45 \%$ & $43.15 \%$ & $1.11 \%$ & $1.32 \%$ \\
\hline & EDF Energy & $31.42 \%$ & $22.51 \%$ & $8.01 \%$ & $35.79 \%$ & $2.27 \%$ & $1.23 \%$ \\
\hline & RWE npower & $16.60 \%$ & $17.86 \%$ & $3.16 \%$ & $59.80 \%$ & $2.57 \%$ & $1.96 \%$ \\
\hline & SSE & $26.66 \%$ & $16.61 \%$ & $3.70 \%$ & $50.50 \%$ & $2.53 \%$ & $1.65 \%$ \\
\hline & Scottish Power & $31.26 \%$ & $21.91 \%$ & $4.14 \%$ & $42.21 \%$ & $0.47 \%$ & $1.28 \%$ \\
\hline
\end{tabular}

if they can be reduced to fewer dimensions and displayed visually (Andersen 1997; Brown and Suter 2012; Opoku et al. 2006). Therefore, a two-dimensional MCA was used to interpret the five dimensions of brand personality over a two dimensional axis (Hoffman and Franke 1986). Using two dimensions is appropriate given the high proportion of variance explained by the first two eigenvectors, which accounted for $86.8 \%$ of the total variance. The correspondence analysis explained percentages (eigenvalues) in variance of $75.4 \%(0.052)$ for the first dimension and $13.4 \%$ (0.009) for the second dimension. Eigenvalues represent the linear transformation; the two-dimensions of brand personality strength and consistency should be interpreted independently. Furthermore, a multi-dimensional axis eliminates problems related to inter-spatial differences (Greenacre 2010; Hoffman and Franke 1986). Using MCA we were able to visually probe the relationship between brand personality strength and consistency. The six energy brands' websites and annual reports in relation to the five brand personality dimensions were plotted in Figure 2 using two-dimensional correspondence analysis.

The data were checked for outliers using a box plot. The six energy brands' websites and annual reports in relation to the five brand personality dimensions were plotted in Figure 2 using two-dimensional correspondence analysis. The two-dimensions of brand personality strength and consistency should be interpreted independently.

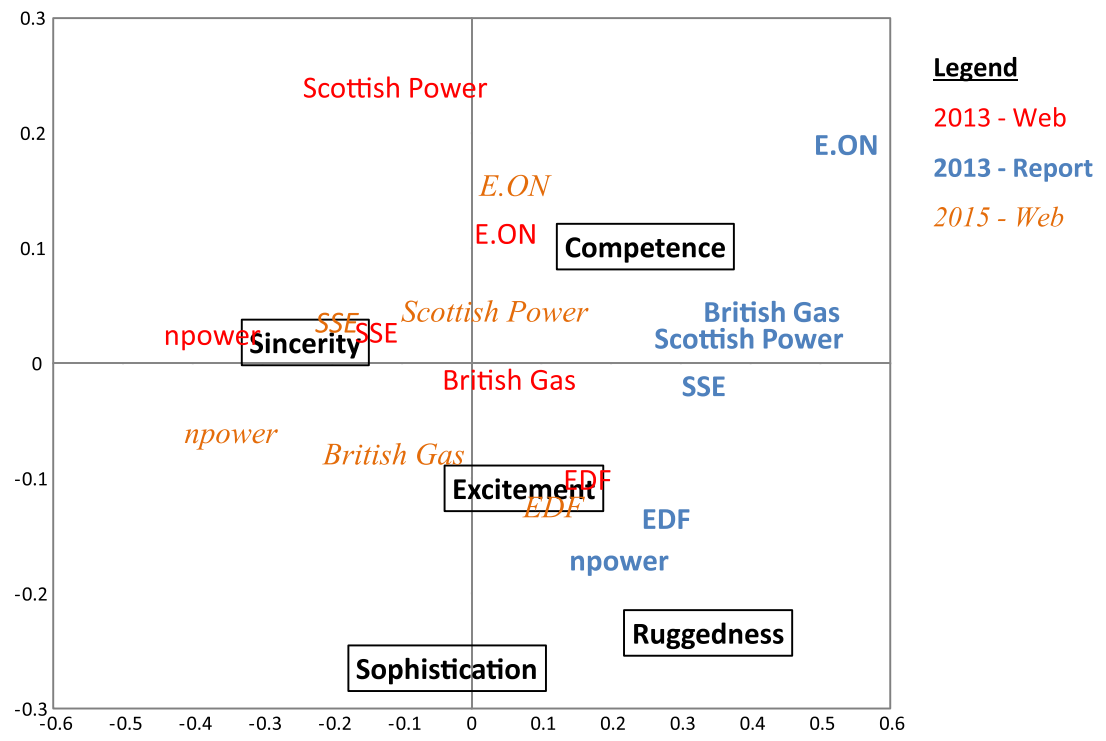

Figure 2 Correspondence map of brand personality of the Big Six brands in, 2013 (web and annual statement) and, 2015 (web) [Colour figure can be viewed at wileyonlinelibrary.com] 
The correspondence analysis explained percentages (eigenvalues) in variance of $75.4 \%(0.052)$ for the first dimension and $13.4 \%$ (0.009) for the second dimension. Eigenvalues represent the linear transformation; the two-dimensions should be interpreted independently.

The data were checked for outliers using a box plot. The data were then tested for normality, linearity, homoscedasticity and independent errors. No assumptions were violated and no evidence suggested that the data were not suitable for further analyses (Field 2009) and the relationships between brand personality and consistency, and performance were statistically analysed. The hypotheses were tested using multiple linear and moderation regressions.

\section{Analysis and findings}

The first part of this section analyses the MCA and relationships between the dimensions and positions of the Big Six energy companies. The second part tests the statistical relationship between brand personality dimensional strength and performance. The third section tests the statistical relationship between consistency over time and between media, and performance. The final section content analyses the words used to form particular dimensions that the energy brands communicate strongly.

\section{Brand personality positions}

Figure 2 shows that the dimension sincerity lies to the left of the correspondence plot. Conversely, the dimension ruggedness lies to the right. Thus, we can interpret the horizontal axis as if it separates the more sincere from the more rugged energy brands. And we can interpret the vertical axis as if it measures the level of excitement and sophistication. Since the horizontal axis is the primary dimension, movement along this dimension represents the greatest variance, whilst the vertical axis represents a more subtle difference in a brand's personality.

The correspondence analysis map in Figure 2 shows that: British Gas communicated a mixture of competence, sincerity and excitement in, 2013, however by, 2015 had moved towards excitement and sophistication. Their annual report communicated competence strongly. EON Energy communicated competence strongly and consistently through their website (in, 2013 and, 2015) and through their annual report. EDF Energy communicated excitement and competence relatively consistently through their website (between, 2013 and, 2015) and annual report. Npower communicated sincerity strongly through their website in, 2013. In, 2015 they were moving towards excitement, whilst still communicating sincerity strongly. Their annual report communicated ruggedness strongly. SSE communicated sincerity strongly through their website (in, 2013 and, 2015) and communicated a mixture of competence and ruggedness through their annual report. Scottish Power did not communicate a distinct personality in, 2013, but moved to a more competent, sincere and exciting personality in, 2015. Their annual report communicated competence and ruggedness.

Visually, these findings indicate that the Big Six energy brands are indeed communicating varied brand personalities. It can clearly be seen that certain energy brands have communicated their personality consistently, whilst others seem to have repositioned themselves. The next section uses statistical analysis to relate the brand personalities to performance.

\section{Brand personalities and performance}

Multiple linear regression was used to test hypothesis 1 . Brand personality competence, excitement, sophistication, ruggedness and sincerity were regressed against switching. We have used switching, that is, the number of customers a firm is losing to its competitors, as a proxy for firm performance. Indeed, in the electricity retail market, increasing the customer base (market power) is fundamental to the success of a firm.

Brand personality explained a significant amount of the variance in switching $\left(\mathrm{R}^{2}=0.727, p<0.001\right)$. The analysis showed that brand personality competence ( $\beta=1.430, p<0.05)$, excitement $(\beta=-1.578, \mathrm{p}=<$ $0.001)$, ruggedness $(\beta=-1.434, \mathrm{p}<0.001)$ and sincerity ( $\beta=0.948, \mathrm{p}<0.001)$ contributed significantly, whilst Sophistication ( $\beta=0.332$, ns) did not. Therefore, hypotheses $\mathrm{H} 1(\mathrm{~b}), \mathrm{H} 1(\mathrm{c})$ and $\mathrm{H} 1(\mathrm{~d})$ were supported, whilst hypotheses $\mathrm{H} 1$ (a) and $\mathrm{H} 1$ (e) were not. Brand personality excitement and ruggedness were negatively (less) associated with switching, whilst competence and sincerity were positively (more) associated with switching. In other words, brands that communicated excitement and ruggedness strongly and competence and

Table 7 Market share change (account volume) and average website dimension strengths (ranked)

\begin{tabular}{lcccccc}
\hline & $M S$ & Competence & Excitement & Ruggedness & Sincerity & Sophistication \\
\hline EDF Energy & 1 & 3 & 1 & 1 & 6 & 3 \\
Scottish Power & 2 & 2 & 2 & 2 & 4 & 6 \\
British Gas & 3 & 4 & 3 & 3 & 5 & 2 \\
E.ON UK & 4 & 1 & 5 & 5 & 5 & 3 \\
SSE & 5 & 5 & 4 & 5 & 1 & 4 \\
RWE npower & 6 & 6 & 5 & 5 & \\
\hline
\end{tabular}


sincerity weakly experienced the least switching and hence, the strongest performance. Table 7 provides a high level view of the two-year period and average brand personality strength, as communicated through the website.

\section{Brand personality consistencies and performance}

The level of brand consistency over time significantly predicted consumer switching $\left(\beta=0.232, \mathrm{R}^{2}=0.658\right.$, $\mathrm{p}<0.001)$. Hypothesis 2 is therefore supported. Thus, brands which had significantly changed their brand personality position or communicated inconsistently between, 2013 and, 2015 had more switching than those brands which remained consistent. The level of brand consistency between the website and annual report significantly predicted consumer switching ( $\beta=0.227$, $\left.\mathrm{R}^{2}=0.251, \mathrm{p}<0.001\right)$. Hypothesis 3 is therefore supported. So brands which have a significantly different brand personality position between marketing communication channels had more switching than those brands which remained consistent.

To explain the positive relationship between brand consistency and switching, it cannot be assumed that the measured consistency (or lack thereof) is apparent to consumers. Specifically, it is reasonable to expect that the vast majority of consumers will not read both the annual reports and websites of any electricity provider. However, the minority of consumers who are switching may be those who are actively engaging with providers and seeking more information about them through these additional sources. Furthermore, it should be stressed that the comparison of brand personalities reflected in annual reports and websites is a proxy for the brand consistency which may be reflected in a number of other communication avenues between the firms and their stakeholders. Finally, it can be argued that reports and websites are reviewed more thoroughly by organizations and individuals that act as public influencers such as comparison websites and consumer advice organizations.

\section{Evidencing brand personalities}

British Gas, as a former state owned utility, had a brand personality that was for many years based around its competencies, stability and lack of change (Parker 2003). Thus in, 2013, its annual report predominantly concentrated on its competencies, particularly to 'ensure the successful implementation of [..] strategic priorities' aiming to be an organization 'leading the industry' through 'ensuring continued safe, reliable operation' through 'strong underlying economics and investment'. Prior to, 2013, at the height of the public's concerns over increasing prices, British Gas changed its visual identity for the first time in seventeen years (Chapman 2011). It began to stress that it was more customer focused, a modern brand, and started to push its green credentials (visually, by adding green to its logo) and as a part of its personality. Thus, whilst its website communicated competence, it also communicated sincerity and excitement. Excerpts from their website explained the 'competence and experience of British Gas engineers' as well the importance of 'having an honest conversation with customers, then acting on the feedback' which included introducing an 'exciting new tariff [..] of $100 \%$ British renewable sources - at the same price as our Standard tariff'. In, 2014, a new marketing director was appointed (McCarthy 2014), charged with growing British Gas brand awareness. This has led the brand in the direction of excitement, with the, 2015 website evolving to be less competent and sincere in favour of a more exciting brand personality. The company explained it was looking 'after customers' worlds everyday by providing [...] innovative energy solutions' and offering 'the most exciting products on the market'.

E.ON, having changed its name from Powergen in, 2002, was arguably in the best position to craft its brand personality from scratch (Thomas 2003) for the UK market. E.ON Energy communicated competence strongly and consistently through its marketing material. The annual statement explained the role of the executive board to 'regularly report on a timely and comprehensive basis on all relevant issues of strategy, planning, business development' which pivots around the 'design of superior products and services for customers'. The company wanted a 'strong emphasis on working with employees' to ensure all 'processes are complete and comprehensive'. Interestingly, E.ON (2008) has publicly announced that its brand is designed for "consumers to control their own experience $[\ldots]$ to put across the personality behind $\mathrm{E}$. ON', thus their website seemed concerned with explaining their long term, competent strategies and emphasized their 'responsibility for securing access to long term gas storage projects in the UK' and to 'secure and deliver low carbon electricity' through 'award winning projects'. Emphasis was also placed on 'enhancing employee skills and competence' to create 'responsible, competent leaders' as well as products being 'independently certified to confirm that it meets Ofgem's' standards.

EDF Energy was consistent between all media, whilst communicating excitement strongly. EDF stress that their brand personality is 'Positive Energy' and unchanged in three ways: that it is bold, optimistic and visionary (EDF 2013). In, 2013, EDF introduced their blob-character Zingy to the UK, in an effort to help it stand out from the other five providers within the Big Six. Through their website, EDF explain how they 'boost UK-wide carbon reduction efforts' through 'innovative energy solutions' and 'exciting innovative projects'; for example 'newly opened state of the art' facilities emphasizing 'energy through sustainability [...] and innovation [which is of] vital importance in energising communities'. In, 2014, 
EDF held regular workshops for its UK staff to help them keep its excitement-based personality strong across various media (EDF 2014). Given these efforts, it is perhaps unsurprising that EDF were the most consistent and exciting energy brand. Thus the annual statement appeared consistent with the website, albeit for a different audience, explaining how E.ON 'offers customers a full range of state-of-the-art integrated solutions' through 'projects and the expansion and modernisation of existing generation assets'.

Since, 2004, Scottish Power has elected to use an external branding agency. The mandate was to soften the firm's image (D8 2015) with greater focus on a more organic feel. In this regard, the website predominantly communicated sincerity in, 2013, with emphasis to 'ensure [customers] are paying the correct amount' through ensuring that 'actual register readings [...] are validated' and that 'operational procedures are straightforward, robust and transparent'. In, 2015, the website moved to a more sincere, but also competent position through emphasis on customization 'easily, leading to a superior, more personalised service' through the development of an 'award winning registration process that is tailored for every customer'. Whilst Scottish Power's brand strategy was predominately concerned with 'every single consumer touch point', the annual report communicated a mixture of competence and ruggedness with a mix of strategic information such as 'internal staff and external advisers working on the business plan; strong executive oversight; and a manager appointed to improve stakeholder engagement', also explaining the role of 'promoting a robust control[ed] environment' of which they achieve a high level of 'detection of fraud and other irregularities'.

Npower have manoeuvred their brand personality between, 2013 and, 2015. In, 2013, it was reported that the company wished to promote 'customer focused' and 'consistent' personality across all touch points, to earn the right from customers to 'be trusted', moving away from their 'low price' proposition (Brownsell 2013). Npower's annual report communicated ruggedness strongly, explaining 'difficult framework conditions' and plants which have been 'especially hard hit by the rise in electricity from renewable' and in response their 'goals of sustainable management becoming more robust'. Thus in, 2013, presumably to 'earn trust' from customers, the website began communicating sincerity strongly, in order 'build sustainable relationships' with customers, by providing a 'warm responsive service'. Sometime after this, the company employed a brand consultancy to change the tone of the brand by utilizing more 'lifestyle' imagery and create a more 'distinct personality' (CHSCreative 2014). Thus by, 2015 the website appeared more exciting offering a competition and 'prizes for the most spine-tingling shriek of excitement' as well as a fast
'5 minute check to see if you're [...] eligible for a brand new energy efficient boiler' which offers to 'save energy and free up vital cash'.

In, 2014, SSE promoted the idea that consumers needed to look again at its offering and created a computer generated imagery (CGI) 'Orangutan', in a bid to 'reinstate consumers' faith and trust' (Bold 2015) in the aftermath of price fixing scandals. Thus during, 2013 and, 2015, SSE communicated sincerity strongly through their website. SSE explained that often competitors offer 'something [which] appears too good to be true [and] it often is' whereas SSE 'offer real solutions' which are 'simple, straightforward prices and products' with 'guaranteed standards [to] ensure the highest levels of service'. In contrast, but perhaps as part of SSE's wider strategy, the annual report communicated a mixture of competence and ruggedness. The report explained its 'award winning customer service' at the 'forefront of industry development', being 'recognised as a leader in delivering high levels of customer service'. SSE contextualized these competencies within an environment of 'economic conditions [which] are tough', referring to price hikes, explaining that 'days like today are especially difficult' and 'hard decisions [to make], particularly in the difficult economic conditions'.

\section{Discussion, managerial implications and conclusions}

Despite the very significant political, economic and even cultural status of the Big Six, little research has been done into the ways in which these companies attempt to differentiate themselves. This is perhaps because, until recently, they have not needed to follow such a strategy in any coherent and consistent way. Under scrutiny from the public and politicians, however, the energy sector is changing rapidly. Branding within the energy sector has become increasingly important, as energy firms seek to attract and importantly retain customers. This study contributes to the branding literature in several ways.

\section{Brand personality strength}

Foremost, in a market otherwise characterized by isomorphism (Provance et al. 2011), this research highlighted the differing configurations of brand personality dimensions being used by energy sector companies and which dimensions of brand personality had greatest impact. Favourable brand personality has been demonstrated to increase consumer usage and preference towards a product or service (Sirgy 1982; Freling and Forbes 2005). Geuens (2004) explains that in markets where it is difficult to evaluate between different competitive offerings, such as for energy markets, the role of a strong brand position and 
communication becomes more important (Novak and Lyman 1998). In the age of multiple stakeholders, consumers want to know more about the company behind the products and services (Gyrd-Jones et al. 2013) and this is assisted by the corporate brand personality. However, our findings have shown that a strong brand personality alone is not enough to prevent consumer switching, but rather that particular dimensions of personality are more favourable than others and that the relevance of specific personality traits can change.

Sincerity as a dimension of brand personality produced counterintuitive results in this study. Trustworthiness as a branding feature was previously identified by ApaolazaIbáñez et al. (2006) as one of the main drivers for customer loyalty in the Spanish residential electricity market, but our findings refute this conclusion for the UK market. Given that sincerity is linked to trust in the brand, which represents honesty and reliability (Moorman et al. 1993), it was an underlying trait of most energy brands, but was associated with more switching. Aaker et al. (2004), found that in transgression situations, relationships with sincere brands suffer the most. It is possible that due to the negative media coverage of UK energy companies that consumers do not believe the energy companies' projection of the brand personality dimension of sincerity.

Excitement is an underlying dimension of energy brand personalities, and when it appeared more prominently, as a primary or secondary dimension, the lowest levels of switching were observed. Our findings support previous findings, for example of that by Swaminathan et al. (2009) which highlight consumer preference for exciting brands when making high avoidance decisions. Guèvremont and Grohmann (2013), found that excitement is also perceived more positively in line with persuasion attempts. Aaker et al. (2004) identified consumers being more likely to overlook transgressions (for example, problems in service or billing) of exciting brands and that these transgressions may even reinvigorate a relationship once a problem has been resolved (as part of an 'intimate' relationship). Our research demonstrates that it is not only the more dynamic consumer brands that are able to benefit from projecting a more exciting personality.

Ruggedness it emerged was linked to lower consumer switching behaviour, and was linked strongly with an energy brand's green credentials. Hartmann and ApaolazaIbáñez (2012) highlight the benefits of green branding strategies in attracting and retaining consumers and Hanimann et al. (2015) identified green branding to be positively related to consumer demand. However, our findings can only offer limited support for this within the UK market, as no energy brands communicated Ruggedness strongly through their website and only npower highlighted their green credentials in their annual report.
Competence was another dimension that led to counterintuitive findings in this study. Increased levels of competence (and to a lesser extent, sincerity) were associated with more consumers switching, which led to a decrease in market share. Given that competence was the dimension most likely to be related to the sector (Sung and Kim 2010) it may be that, as Beverland and Farrelly (2010) explain, consumers pursue authentic products, that is, those perceived as genuine, real and true. In line with Beverland and Farrelly's findings, it could be that consumers expect competence from their energy company, they take it for granted and thus overtly communicating these dimensions to consumers may be subject to a level of cynicism and therefore viewed as inauthentic.

Sophistication was the least communicated dimension and was not significant. Given that sophisticated brands are most likely to be associated with higher costs and exclusivity (Maehle et al. 2011), perceived higher price does not tend to fit the mainstream energy market.

\section{Brand personality consistency}

The findings of this research have highlighted the importance of consistency between media communications. The corporate brand covers the entire company and a covenant between a company and its major stakeholder groups is at the core of the corporate brand (Balmer 2001; Balmer et al. 2001; Argenti and Druckenmiller 2004). de Chernatony and Segal-Horn (2003) explain that successful service brands are able to communicate a clear brand position consistently to all major stakeholders. This research demonstrates that annual reports often communicated higher levels of competence (in terms of achievement) and ruggedness (in terms of green credentials) than other media, often at the expense of consistency. The importance of image in annual reports has been noted in previous research (Stanton et al. 2004) and was noted as particularly useful when countering negative information. The findings of this study highlight competence was used in conjunction with reporting negative information (for example: significant price hikes and missing renewable targets) and findings highlight that these deviations were often at the expense of brand personality consistency, communicated via their websites. EDF stood out as particularly successful, being able to communicate a position of excitement strongly and consistently, while at the same time communicating an increased amount of competence in its annual report.

Our findings have demonstrated that consistent brands performed better as they achieved higher consumer retention than their inconsistent counterparts. Aaker (1996b), explains the advantages of a consistent brand position over time as being able to achieve communication efficiencies to contribute to owning a position in the minds of consumers. Aaker (1996b), suggests that brands are 
under increasing pressure to change position if short-term performance targets are not met. Our findings indicate that energy brands, particularly npower and Scottish Energy, made significant changes to their brand personality, which coincided with press releases in regard to changes in their strategy, but they suffered higher levels of switching and a subsequent reduction in market share.

In summary, in addition to responding to the call for empirical evidence into links between brand and loyalty in liberalized residential energy markets, this research provides a theoretical contribution to branding and marketing research within the energy sector by exploring and linking brand personality and consistency to performance. The study has been achieved through the application of new combinations of tools and analyses to measure brand personality and consistency within the energy context. Using these tools, researchers and managers are able to analyse the brand personality communicated via marketing channels, as well as to measure consistency between channels and over time.

\section{Managerial implications}

Energy managers are aware of the importance of their image and brand. One needs to look no further than EDF's online 'Brand Centre' to appreciate how seriously the Big Six are taking their brand development (EDF 2013). With separate sections for both external and internal stakeholders, companies such as EDF are now determined to ensure that their branding efforts coalesce into a repeated message to consumers. That message plays an important role in forging the brand personality of the company. The kind of brand-focused thinking which in the past has been confined to forward-looking companies such as Apple, is now becoming an integral part of corporate strategy more widely. Nonetheless, some of the energy brands still struggle to carve out an identity for themselves and the findings of this research provide three clear managerial and practical implications.

First, there is an ideal brand personality for the UK energy sector. Low to medium levels of sincerity and competence and high levels of excitement and ruggedness communicated through the website lead to better performance. The annual report should maintain this, but also communicate a higher level of competence. Energy sector brand managers should review their communications and ensure that they are using the right language to portray their brand personality to their customers.

Second, brand personality consistency over time is important. Energy sector brands should not drastically change their branding each year. If change is deemed necessary, incremental changes should be introduced. Managers should detect and correct potential inconsistencies in their branding by regularly reviewing their external communications.
Finally, brand personality consistency between the website and the annual report was identified as a predictor of performance. Interestingly, the majority of brands were inconsistent on this measure. Relatively quick gains could be made by energy sector brand managers by reviewing external communications for consistency of language and message. Our findings highlight that brand personality should be consistent between these media, but greater emphasis needs to be placed on Competence related language, particularly when delivering negative information.

\section{Conclusions}

This research has extended the current understanding of brands and brand personality into the energy sector. Previous research has tended to focus on pricing, but since privatization of the UK energy sector, increasing focus has been placed on marketing and branding. By focusing on energy sector companies brand communication through their websites and annual reports, we examined what brand personality dimensions are communicated most strongly and how consistently each organization communicates its brand between the website and annual report. We then assessed the organization's performance, measured by consumer loyalty or switching behaviour. We find that brand personality does have an impact on customer retention. First, brands communicating excitement more strongly have the lowest levels of switching. Second, brands with more consistent brand personalities have lower levels of switching. Brand managers should therefore consider how to increase the communication of excitement in relation to their brands without being inauthentic and they need to ensure that their brand is consistent over time and between different marketing media. This research has used an innovative measure of performance - consumer switching. Future studies could utilize other performance data, such as green credentials, sustainability levels, price comparison data, profitability data or performance on complaints. This study is based in the UK and considers brand personality strength, brand personality consistency and performance for the UK Big Six energy providers. The results may not therefore be generalizable to other countries and organizational contexts. It would be useful to extend this research to energy providers in other countries to investigate the extent to which the entire sector is embracing branding and brand personality. This research focuses on the textual marketing communications of the energy providers in the sample and does not consider other aspects that contribute to brand personality consistency such as logo, graphics, colour, shapes and layout of communications. The study focuses on what the brand is communicating about itself via its annual 
report and website, and not on what consumers perceive the brand personality to be from these channels. Consumer perception of the brand personality and its consistency across other media is therefore another interesting and useful area for further research.

\section{Acknowledgments}

The specific study has been funded under the project TILOS (Horizon, 2020 Low Carbon Energy Local / small-scale storage LCE-08-, 2014). This project has received funding from the European Union \& Horizon, 2020 research and innovation programme under Grant Agreement No 646529. The authors thank Cornwall Energy Associates Ltd for providing market data on the 'big six' UK energy suppliers.

\section{References}

Aaker, D., 1996a. Building strong brands. New York: Free Press.

Aaker, D. A., 1996b, "Resisting temptations to change a brand position/execution: The power of consistency over time". Journal of Brand Management, 3: 251-258.

Aaker, J., 1997, "Dimensions of brand personality". Journal of Marketing Research, 34: 347-356.

Aaker, J., S. Fournier and S. A. Brasel, 2004, "When good brands do bad". Journal of Consumer Research, 31: 1-16.

Ahmed, M. and M. T. Jan, 2015, “An extension of Aaker's brand personality model from Islamic perspective: A conceptual study". Journal of Islamic Marketing, 6: 388-405.

Andersen, E. B., 1997. Introduction to the statistical analysis of categorical data. Springer, Berlin, Heidelberg: Springer Verlag.

Apaolaza-Ibáñez, V., P. Hartmann and P. Zorrilla Calvo, 2006, "Antecedents of customer loyalty in residential energy markets: Service quality, satisfaction, trust and switching costs". The Service Industries Journal, 26: 633-650.

Argenti, P. A. and B. Druckenmiller, 2004, "Reputation and the corporate brand". Corporate Reputation Review, 6: 368-374.

Ariely, D., 2009. Predictably irrational, revised and expanded edition: The hidden forces that shape our decisions. London: HarperCollins.

Arruda, W., 2009, "Brand communication: The three Cs". Thunderbird International Business Review, 51: 409-416.

Balmer, J., 2001, "Corporate identity, corporate branding and corporate marketing-seeing through the fog". EuropeanJournal of Marketing, 35: 248-291.

Balmer, J. M. T., 2013, "Corporate brand orientation: What is it? What of it?" Journal of Brand Management, 20: 723-741.

Balmer, J., F. Harris and L. de Chernatony, 2001, "Corporate branding and corporate brand performance". European Journal of Marketing, 35: 441-456.

Batra, R., D. R. Lehmann and D. Singh, 1993. Brand equity and advertising. Hillsdale, NJ: Lawrence Erlbaum Associates.

Bawden, T., 2015. 'UK's stale energy market makes it easy for Big Six to hike prices,' says new study. Independent. Available from http://www.independent.co.uk/news/uk/politics/uk-s-stale- energy-market-makes-it-easy-for-big-six-to-hike-prices-saysnew-study-9001778.html (accessed 20 October 2015).

BBC, 2013a. "Cameron 'frustrated' by dominance of six energy firms". Available from http://www.bbc.co.uk/news/uk-politics24706853 (accessed 20 November 2013).

BBC, 2013b. "Electricity switching numbers at record low". (accessed 21 November 2013). Available from http://www. bbc.co.uk/news/business-24288084.

Becker, C. and S. Palmér, 2009. "Branding in universities: Identity versus image". Published master dissertation, Lulea University of Technology.

Berelson, B., 1952. Content analysis in communication research. New York: Free Press.

Beverland, M., 2009. Building brand authenticity: 7 habits of iconic brands. London: Palgrave Macmillan.

Beverland, M. B. and F. J. Farrelly, 2010, "The quest for authenticity in consumption: Consumers' purposive choice of authentic cues to shape experienced outcomes". Journal of Consumer Research, 36: 838-856.

Bold, B., 2015. SSE creates CGI orangutan in bid to reinstate consumer trust in energy firms. marketing magazine, 2014. Available from http://www.marketingmagazine.co.uk/article/ 1316013/sse-creates-cgi-orangutan-bid-reinstate-consumertrust-energy-firms (accessed 1 January 2015).

Bonk, B., 2012. Die energiewende im kopf: Neuromarketing zur gezielten markenbildung im ökostromsektor: Hamburg: Diplomica Verlag.

Brakus, J. J., B. H. Schmitt and L. Zarantonello, 2009, "Brand experience: What is it? How is it measured? Does it affect loyalty?" Journal of Marketing, 73: 52-68.

Braunstein, J. R. and S. D. Ross, 2010, "Brand personality in sport: Dimension analysis and general scale development". Sport Marketing Quarterly, 19: 8-16.

Brei, V. and S. Böhm, 2014, " $1 \mathrm{~L}=10 \mathrm{~L}$ for Africa': Corporate social responsibility and the transformation of bottled water into a 'consumer activist'commodity". Discourse \& Society, 25: 3-31.

Brocklehurst, C., 2013. LinkedIn profile: Head of brand marketing at British gas. LinkedIn, 2013. Available from http://www.linkedin.com/pub/chris-brocklehurst/38/321/81 (accessed 25 November 2013).

Brookes, M., 2003, "Higher education: Marketing in a quasicommercial service industry". International Journal of Nonprofit and Voluntary Sector Marketing, 8: 134-142.

Brown, T. J. and T. A. Suter, 2012. MR (with Marketing CourseMate with eBook Printed Access Card) 1st Edition. Available from https://www.amazon.com/MarketingCourseMate-eBook-Printed-Access/dp/1111532400

Brownsell, A., 2009. "EDF Group plots 'leader' identity". Marketing Magazine. Available from http://www. marketingmagazine.co.uk/article/897123/edf-group-plotsleader-identity (accessed 25 November 2013).

Brownsell, A., 2013. "Npower: 'We needed to earn the right to engage with customers". Marketing Magazine. Available from http://www.marketingmagazine.co.uk/article/1193228/npowerwe-needed-earn-right-engage-customers (accessed 25 November 2013).

Chapleo, C., 2007, "Barriers to brand building in UK universities?' International Journal of Nonprofit and Voluntary Sector Marketing, 12: 23-32. 
Chapman, M., 2011. "British gas set to modernise brand identity". Marketing Magazine,. Available from http://www. marketingmagazine.co.uk/article/1096711/british-gas-setmodernise-brand-identity (accessed 25 November 2013).

de Chernatony, L., 2010. Creating powerful brands. Routledge. de Chernatony, L. and S. Segal-Horn, 2003, "The criteria for successful services brands". European Journal of Marketing, 37: 1095-1118.

Chioveanu, I. and J. Zhou, 2013, "Price competition with consumer confusion". Management Science, 59: 2450-2469.

Churchill, G. A., T. J. Brown and T. A. Suter, 1992. Basic marketing research. Fort Worth, TX: Dryden Press.

CHSCreative, 2014. "NPower case study: New brand positioning". Available from http://www.chscreative.com/ clients/npower/new-brand-positioning/ (accessed 2 February 2015).

Clancy, D. and D. O'Loughlin, 2002, "Identifying the "energy champion': A consumer behaviour approach to understanding the home energy conservation market in Ireland". International Journal of Nonprofit and Voluntary Sector Marketing, 7: 258-270.

Clemenz, J., M. Brettel and T. Moeller, 2012, "How the personality of a brand impacts the perception of different dimensions of quality". Journal of Brand Management, 20: $52-64$.

D8, 2015. "ScottishPower: Case study". Available from http://d8. uk/case-studies/scottishpower (accessed 15 May 2015).

Daglish, T., 2016, "Consumer governance in electricity markets". Energy Economics, 56: 326-337.

Dowling, G. R., 2006, "Communicating corporate reputation through stories". California Management Review, 49: 82-100.

EDF, 2013. "EDF energy: Brand centre". Available from http:// brandcentre.edfenergy.com/content_uk/index.php (accessed 25 November 2013).

EDF, 2014. "Our latest news". Available from https://brandcenteren.edf.com/our-brand/our-latest-news-210178.html (accessed 5 May 2015).

Eggers, F., M. O'Dwyer, S. Kraus, C. Vallaster and S. Güldenberg, 2012. "The impact of brand authenticity on brand trust and SME growth: A CEO perspective". Journal of World Business, 48: 340-348.

Erdem, T. and J. Swait, 1998, "Brand equity as a signaling phenomenon". Journal of Consumer Psychology, 7: 131-157.

Fetscherin, M. and M. Toncar, 2010, "The effects of the country of brand and the country of manufacturing of automobiles: An experimental study of consumers' brand personality perceptions". International Marketing Review, 27: 164-178.

Field, A. P., 2009. Discovering statistics using SPSS. London: Sage publications.

Freling, T. H. and L. P. Forbes, 2005, "An empirical analysis of the brand personality effect". Journal of Product \& Brand Management, 14: 404-413.

Gangale, F., A. Mengolini and I. Onyeji, 2013, "Consumer engagement: An insight from smart grid projects in Europe". Energy Policy, 60: 621-628.

García-Acebrón, C., R. Vázquez-Casielles and V. Iglesias, 2010, "The effect of perceived value and switching barriers on customer price tolerance in industrial energy markets". Journal of Business-to-Business Marketing, 17: 317-335.
Geuens, M., 2004, "Editorial: Strategic brand communications". Journal of Marketing Communications, 10: 69-71.

Giulietti, M., C. Waddams Price and M. Waterson, 2005, "Consumer choice and competition policy: A study of UK energy markets". The Economic Journal, 115: 949-968.

Goett, A. A., K. Hudson and K. E. Train, 2000, "Customers' choice among retail energy suppliers: The willingness-to-pay for service attributes". Energy Journal, 21: 1-28.

Grant, J., 1999. The new marketing manifesto: The 12 rules for successful marketing in the 21st century. London: Orion Business.

Greenacre, M., 2010. Correspondence analysis in practice. London: Chapman and Hall/CRC.

Guèvremont, A. and B. Grohmann, 2013, "The impact of brand personality on consumer responses to persuasion attempts". Journal of Brand Management, 20: 518-530.

Guthrie, M., H.-S. Kim and J. Jung, 2008, "The effects of facial image and cosmetic usage on perceptions of brand personality". Journal of Fashion Marketing and Management: An International Journal, 12: 164-181.

Gyrd-Jones, R. I., C. Helm and J. Munk, 2013, "Exploring the impact of silos in achieving brand orientation". Journal of Marketing Management, 29: 1056-1078.

Haarhoff, G. and N. Kleyn, 2012, "Open source brands and their online brand personality". Journal of Brand Managemen, 20: 104-114.

Hammond, E. M., D. R. Helm and D. J. Thompson, 1985, "British gas: Options for privatisation". Fiscal Studies, 6: 1-20.

Hanimann, R., J. Vinterbäck and C. Mark-Herbert, 2015, "Consumer behavior in renewable electricity: Can branding in accordance with identity signaling increase demand for renewable electricity and strengthen supplier brands?" Energy Policy, 78: 11-21.

Harris, E. G. and D. E. Fleming, 2005, “Assessing the human element in service personality formation: Personality congruency and the five factor model". Journal of Services Marketing, 19: 187-198.

Hartmann, P. and V. Apaolaza-Ibáñez, 2007, "Managing customer loyalty in liberalized residential energy markets: The impact of energy branding". Energy Policy, 35: 2661-2672.

Hartmann, P. and V. Apaolaza-Ibáñez, 2012, "Consumer attitude and purchase intention toward green energy brands: The roles of psychological benefits and environmental concern". Journal of Business Research, 65: 1254-1263.

He, X. and D. Reiner, 2016. "Why do more british consumers not switch energy suppliers? The role of individual attitudes". Energy Policy Research Group. Available from https:/www.repository.cam.ac.uk/bitstream/handle/1810/ 255342/cwpe1525.pdf? sequence=1\&isAllowed=y (accessed 15 January 2016).

Herbes, C. and I. Ramme, 2014, "Online marketing of green electricity in Germany: A content analysis of providers' websites". Energy Policy, 66: 257-266.

Heugens, P. P. M. A. R., 2002, "Managing public affairs through storytelling". Journal of Public Affairs, 2: 57-70.

Hoffman, D. L. and G. R. Franke, 1986, "Correspondence analysis: Graphical representation of categorical data in marketing research". Journal of Marketing Research, 23: 213-227. 
Holmes, A., 2016. Commoditization and the strategic response. Florida: CRC Press.

House of Commons Work and Pensions Committee and T. Rooney., 2009. Fuel poverty: Oral and written evidence, Wednesday 24 June, 2009, Mr David kidney MP, Ms pam Wynne, Helen Goodman MP. London: Stationery Office.

Ind, N. and R. Bjerke, 2007. Branding governance: A participatory approach to the brand building process. Chichester: John Wiley \& Sons.

Interbrand, 2012a. "The electric company: Positioning an energy leader". Available from http://www.interbrand.com/en/ourwork/EDF.aspx (accessed 25 November 2013).

Interbrand, 2012b. "Interbrand: Best global brands, 10 principles of brand strength". Available from http://www.interbrand.com/ en/best-global-brands/best-global-brands-methodology/BrandStrength.aspx (accessed 25 September 2012).

Kaenzig, J., S. L. Heinzle and R. Wüstenhagen, 2013, "Whatever the customer wants, the customer gets? Exploring the gap between consumer preferences and default electricity products in Germany". Energy Policy, 53: 311-322.

Kapferer, J. N., 2008. The new strategic brand management: Creating and sustaining brand equity long term, 4th ed. London: Kogan Page Ltd.

Kassarjian, H. H., 1977, "Content analysis in consumer research". Journal of Consumer Research, 4: 8-18.

Kay, J. A. and D. J. Thompson, 1986, "Privatisation: A policy in search of a rationale". The Economic Kournal, 96: 18-32.

Keller, K. L., 1999, "Managing brands for the long run: Brand reinforcement and revitalization strategies". California Management Review, 41: 102-124.

King, S., 1970. What is a brand. London: J. Walter Thompson.

Knox, S. and D. Bickerton, 2003, "The six conventions of corporate branding". European Journal of Marketing, 37: 998-1016.

Krippendorff, K., 2004. Content analysis: An introduction to its methodology. California: Sage Publications.

Landale, J., 2017. "Ed Miliband: Labour would freeze energy prices". BBC. Available from http://www.bbc.co.uk/news/ukpolitics-24213366 (accessed 17 July 2017).

Lange, F. and M. Dahlén, 2003, "Let's be strange: Brand familiarity and ad-brand incongruency". Journal of Product \& Brand Management, 12: 449-461.

Leggett, J., 2013. The energy of nations: Risk blindness and the road to renaissance. London: Taylor \& Francis.

Lekakis, E. J., 2012, "Will the fair trade revolution be marketised? Commodification, decommodification and the political intensity of consumer politics". Culture and Organization, 18: 345-358.

Maehle, N., C. Otnes and M. Supphellen, 2011, "Consumers' perceptions of the dimensions of brand personality". Journal of Consumer Behaviour, 10: 290-303.

Matthiesen, I. and I. Phau, 2005, "The HUGO BOSS connection: Achieving global brand consistency across countries". The Journal of Brand Management, 12: 325-338.

McCarthy, J., 2014. "British gas appoints Margaret Jobling as brand and marketing director". The Drum. Available from http://www.thedrum.com/news/2014/07/18/british-gasappoints-margaret-jobling-brand-and-marketing-director (accessed 5 May 2015).
McDermott, J., 2013. "The real big six - The problems with Britain's energy market". Financial Times. Available from http://blogs.ft.com/off-message/2013/10/21/the-real-big-sixthe-problems-with-britains-energy-market/ (accessed 16 November 2013).

Milligan, B., 2017. "How would the tory energy price cap work?" BBC. Available from http://www.bbc.co.uk/news/business39694183 (accessed 17 July 2017).

Mingione, M., 2015, "Inquiry into corporate brand alignment: A dialectical analysis and directions for future research". Journal of Product \& Brand Management, 24: 518-536.

Moorman, C., R. Deshpande and G. Zaltman, 1993, "Factors affecting trust in market research relationships". The Journal of Marketing, 57: 81-101.

Müller, M., F. Sensfuß and M. Wietschel, 2007, "Simulation of current pricing-tendencies in the German electricity market for private consumption". Energy Policy, 35: 4283-4294.

Navarro-Bailón, M. Á., 2012. "Strategic consistent messages in cross-tool campaigns: effects on brand image and brand attitude". Journal of Marketing Communications, 18: 189-202.

Novak, E. and M. Lyman, 1998, "Brand positioning: The art of retying connections". The Electricity Journal, 11: 17-22.

Opoku, R. and R. Hinson, 2006, "Online brand personalities: An exploratory analysis of selected African countries". Place Branding, 2: 118-129.

Opoku, R., R. Abratt and L. Pitt, 2006, "Communicating brand personality: Are the websites doing the talking for the top south African business schools?" Journal of Brand Management, 14: 20-39.

Opoku, R., L. F. Pitt, M. Hultman, R. Abratt and S. Spyropoulou, 2007, "What I say about myself: Communication of brand personality by African countries". Tourism Management, 28: 835-844.

Paladino, A. and A. P. Pandit, 2012, "Competing on service and branding in the renewable electricity sector". Energy Policy, 45: 378-388.

Parker, D., 2003, "Performance, risk and strategy in privatised, regulated industries: The UK's experience". International Journal of Public Sector Management, 16: 75-100.

Patterson, A., Y. Khogeer and J. Hodgson, 2013, "How to create an influential anthropomorphic mascot: Literary musings on marketing, make-believe and Meerkats". Journal of Marketing Management, 29: 69-85.

Payne, A. and P. Frow, 1997, "Relationship marketing: Key issues for the utilities sector". Journal of Marketing Management, 13: 463-477.

Pike, S. D., 2004. "Destination brand positioning slogans-towards the development of a set of accountability criteria". Acta Turistica, 16: 102-124.

Pinto, M. B. and A. Yagnik, 2017, "Fit for life: A content analysis of fitness tracker brands use of Facebook in social media marketing". Journal of Brand Management, 24: 1-19.

Pitt, L. F., R. Opoku, M. Hultman, R. Abratt and S. Spyropoulou, 2007, "What I say about myself: Communication of brand personality by African countries". Tourism Management, 28: 835-844.

Plummer, J. T., 1985, "How personality makes a difference". Journal of Advertising Research, 24: 27-31.

Pothitou, M., R. F. Hanna and K. J. Chalvatzis, 2016, "Environmental knowledge, pro-environmental behaviour and 
energy savings in households: An empirical study". Applied Energy, 184: 1217-1229.

Pothitou, M., R. F. Hanna and K. J. Chalvatzis, 2017, "ICT entertainment appliances' impact on domestic electricity consumption". Renewable and Sustainable Energy Reviews, 69: 843-853.

Provance, M., R. G. Donnelly and E. G. Carayannis, 2011, "Institutional influences on business model choice by new ventures in the microgenerated energy industry". Energy Policy, 39: 5630-5637.

Rageh Ismail, A. and G. Spinelli, 2012, "Effects of brand love, personality and image on word of mouth: The case of fashion brands among young consumers". Journal of Fashion Marketing and Management: An International Journal, 16: 386-398.

Richards, P. and E. White, 2014. Simplifying energy tariffs. House of Commons Library: SNSC-6440.

Rommel, K. and J. Meyerhoff, 2009, "Empirische analyse des wechselverhaltens von stromkunden. Was hält stromkunden davon ab, zu ökostromanbietern zu wechseln?" Zeitschrift für Energiewirtschaft, 33: 74-82.

Roper, S. and G. Davies, 2007, "The corporate brand: Dealing with multiple stakeholders". Journal of Marketing Management, 23: 75-90.

Roper, S. and C. Fill, 2012. Corporate reputation, brand and communication. London: Pearson Higher Ed.

Rowlands, I. H., P. Parker and D. Scott, 2004, "Consumer behaviour in restructured electricity markets". Journal of Consumer Behaviour, 3: 272-283.

Rutter, R., C. Hanretty and F. Lettice, 2015, "Political brands: Can parties be distinguished by their online brand personality?" Journal of Political Marketing, 1-20. https://doi. org/10.1080/15377857.2015.1022631.

Rutter, R., S. Roper and F. Lettice, 2016, "Social media interaction, the university brand and recruitment performance". Journal of Business Research, 69: 3096-3104.

Rutter, R., F. Lettice and J. Nadeau, 2017a, "Brand personality in higher education: Anthropomorphized university marketing communications". Journal of Marketing for Higher Education, 27: 19-39.

Rutter, R., J. Nadeau, F. Lettice, M. Lim and S. al Shamaisi, 2017b, "Place branding of seaports in the Middle East". Place Branding and Public Diplomacy. https://doi.org/10.1057/ s41254-017-0072-8.

Shehu, E., J. U. Becker, A.-C. Langmaack and M. Clement, 2016, "The brand personality of nonprofit organizations and the influence of monetary incentives". Journal of Business Ethics, 138: 589.

Shippee, G., 1999, "Market research for electric utilities". The Electricity Journal, 12: 43-50.

Sirgy, M. J., 1982, "Self-concept in consumer behavior: A critical review". Journal of Consumer Research, 9: 287-300.

Sirianni, N. J., M. J. Bitner, S. W. Brown and N. Mandel, 2013, "Branded service encounters: Strategically aligning employee behavior with the brand positioning". Journal of Marketing, 77: $108-123$.
Spear, S. and S. Roper, 2013, "Using corporate stories to build the corporate brand: An impression management perspective". Journal of Product \& Brand Management, 22: 491-501.

Spielmann, N. and B. J. Babin, 2011, "Service with personality: A note on generalizing personality across services contexts". Journal of Services Marketing, 25: 467-474.

Stanton, P., J. Stanton and G. Pires Guil, 2004, "Impressions of an annual report: An experimental study". Corporate Communications: An International Journal, 9: 57-69.

Summerton, J., 2004, "Do electrons have politics? Constructing user identities in Swedish electricity". Science, Technology \& Human Values, 29: 486-511.

Sung, Y. and J. Kim, 2010, "Effects of brand personality on brand trust and brand affect". Psychology \& Marketing, 27: 639-661.

Sung, Y., S. M. Choi, H. Ahn and Y.-A. Song, 2015, "Dimensions of luxury brand personality: Scale development and validation". Psychology \& Marketing, 32: 121-132.

Swaminathan, V., K. M. Stilley and R. Ahluwalia, 2009, "When brand personality matters: The moderating role of attachment styles". Journal of Consumer Research, 35: 985-1002.

Thomas, S., 2003, "The seven brothers". Energy Policy, 31: 393-403.

Thomas, B. J. and S. C. Jenifer, 2016, "Measurement model of employer brand personality a scale construction". Journal of Contemporary Management Research, 10: 58-78.

Tsiotsou, R., 2012, "Developing a scale for measuring the personality of sport teams". Journal of Services Marketing, 26: $238-252$.

Ugolini, M., F. Cassia and V. Vigolo, 2014, "Services branding: Is it a matter of gender?" The TQM Journal, 26: 75-87.

UKRN, 2014. "Consumer engagement and switching". Available from http://www.ukrn.org.uk/wp-content/uploads/2014/12/ Statement-Consumer-engagement-and-switching.pdf (accessed 7 July 2015).

Viktoria Rampl, L. and P. Kenning, 2014, "Employer brand trust and affect: Linking brand personality to employer brand attractiveness". European Journal of Marketing, 48: 218-236.

Walsh, G., K. Dinnie and K.-P. Wiedmann, 2006, "How do corporate reputation and customer satisfaction impact customer defection? A study of private energy customers in Germany". Journal of Services Marketing, 20: 412-420.

Watson, A., H. Viney and P. Schomaker, 2002, "Consumer attitudes to utility products: A consumer behaviour perspective". Marketing Intelligence \& Planning, 20: 394-404.

Wengrow, D., G. Algaze, D. B. Holt, D. Miller, M. S. Rothman, E. Rova, R. Wilk, I. J. Winter and D. Wengrow, 2008, "Prehistories of commodity branding". Current Anthropology, 49: 7-34.

Zafirakis, D., K. J. Chalvatzis and G. Baiocchi, 2015, "Embodied CO 2 emissions and cross-border electricity trade in Europe: Rebalancing burden sharing with energy storage". Applied Energy, 143: 283-300. 